\title{
Populism in Post-Crisis Greece
}

\author{
ABSTRACT \\ Greece was the European nation worst hit by the European Sovereign Debt \\ Crisis, as well as the nation most resistant to reform after it. One of the key \\ reasons for this was the political chaos and rise of populism that came about \\ as a side-effect of the financial crisis. Thus began a new era in Greek politics \\ known as post-metapolitefsi populism. In order to understand how extreme of \\ a case Greece truly is, the case was compared to the theories of Margaret \\ Canovan and Paul Taggart who are both well-respected authors within the \\ scholarly field on populism. The research aimed to test the transferability of \\ two of their theories to that of post-metapolitefsi populism in Greece. \\ Canovan (1999) argues that populism in democracies arises through a gap \\ between the redemptive and pragmatic side of democracy whilst Taggart \\ (2004) presents five features of an 'ideal' type of populism. The research \\ explores how well each key tenet of each theory fits with the rise and \\ functioning of recent populism in Greece.
}

\section{Axel Lönnroth ${ }^{1}$}

\footnotetext{
${ }^{1}$ Axel Lönnroth received a bachelor degree in European Studies at Maastricht University in 2017. At the moment he takes a Master in Public Policy and Human Development at Maastricht University. Contact: a.lonnroth@student.maastrichtuniversity.nI
} 


\section{Introduction}

For a country the size of Greece it has commanded a surprisingly large part of international media since the start of the financial crisis. From being the Eurozone nation worst affected by the European Sovereign Debt Crisis, to a political crisis that generated extreme populism, Greece has suffered blow after blow to an already fragile system. The financial crisis in Greece spearheaded the financial collapse of a number of other European countries such as Spain, Portugal, Ireland, and Italy. However, these nations have all shown signs of recovery. Greece, on the other hand, has not. A large part of this can be attested to the rise of post-metapolitefsi populism. The term Metapolitefsi means regime change and is what the Greeks refer to as the 38 year period between the fall of the dictatorship in 1974 and the June $17^{\text {th }}$ 2012 elections. The period after this election is known, for the time being and is used by a number of key scholars on Greek populism such as Takis Pappas, as post-metapolitefsi (Pappas, 2014, p.8).

On the $23^{\text {rd }}$ July 1974 the previous dictatorship run by the Greek military junta was replaced by political pluralism when Constantine Karamanlis, founder of New Democracy (ND), came to power. He soon began changing Greek society creating a liberal constitution, the formation of large political parties, economic stability and set the groundwork for entering the European Economic Community (EEC) which Greece eventually did in 1981. However, this effort was short lived as Andreas Papandreou, founder of the Panhellenic Socialist Movement (PASOK), "a nominally socialist party that posed in Greece's political arena as the complete antithesis of democratic liberalism" came to power in 1981 (Pappas, 2014, p. 21). During the period of metapolitefsi, the nation experienced three metamorphoses. First, it went from a frail liberal democracy to political extremism characterized by populism. Second, the Greek people went from relative riches to very low standards of living. Lastly, it went from an equal EU partner to an international outcast (Pappas, 2014, p.2). In 2012, the financial crisis would lead to the rise of more extreme populism, primarily: the Coalition of the Radical Left (SYRIZA), the right-winged Independent Greeks (ANEL) and the neo-Nazi Golden Dawn (GD) party. This would be the start of the postmetapolitefsi period.

Already an important question arises: what is meant by populism? A number of scholars differ on the definition of populism. As Margaret Canovan, one of the most prominent scholars in the field states, populism is exceptionally "vague and refers to a bewildering variety of phenomena" (Canovan, 1981, p.3). Pappas (2014) defines populism merely as democratic illiberalism (p.7). This definition has a number of advantages. Firstly, its minimalism allows us to include only the core characteristics of the concept. Second, it not only shows what populism is, but also what it is not by pointing to its "negative pole", political liberalism (Goertz, 2006, p.30). Lastly, it sets this form of populism apart from a non-democratic form of populism such as its authoritarian counterpart.

This chapter will examine to what extent the conventional theories of populism presented by Margaret Canovan (1999) and Paul Taggart (2004) apply to the rise of post-metapolitefsi populism in Greece? The claim is that as Greece suffered from a poorly functioning government prior to the crisis, Canovan and Taggart's theories will not be fully applicable to the Greek case. 
Margaret Canovan (1999) argues that populism arises as the cleavage between the 'redemptive' and 'pragmatic' side of democracy grows too wide. Not only is she a world renowned scholar on the topic, but she has developed a well-established theory on how populism arises. Comparing it to the extreme case of Greece is of interest as it not only shows potential weaknesses of her theories, but likewise how the Greek case differentiates itself from other cases. On the other hand, Paul Taggart (2004) argues that there are five major features of an 'ideal' form of populism. These include; hostile to representative politics, identifies itself with a 'heartland', lacks core values, a reaction to a crisis and has a self-limiting quality. Taggart, like Canovan, is a renowned author within the field. Although his theory is not as compatible with a single case study of Greece as Canovan's, he covers a wider range of functions that populism entails.

This research is of relevance for a number of reasons. First, the Greek case presents an alternative to the existing mainstream scholarly theories. Second, Europe has seen a rise in populist politics after the Sovereign Debt Crisis so understanding how populism arose in the nation worse hit by the crisis can be of great value for nations which still struggle or may suffer an economic crisis in the future (Kriesi \& Pappas, 2015).

To answer this research question the chapter will be set up in the following way. First, a brief explanation of the Greek debt crisis will be provided as it was through this that extreme populism arose. Second, a literature review explaining the existing literature on the broader themes of this topic such as populism situates this research within the academic field. Third, the theoretical framework will present how Canovan saw populism arising and how Taggart believes the populism functions in the real world. Third, a brief description as to why the case of Greece was chosen to compare these theories will be provided. Fourth, this chapter will contextualize the rise of populism in Greece before finally analyzing the theories and comparing them to empirical evidence related to the Greek case.

\section{Greek Sovereign Debt Crisis}

In order to understand how post-metapolitefsi populism could arise it is important to briefly study the situation in Greece at the time. Although the European Sovereign Debt Crisis was an extension of the American sub-prime mortgage crisis (Gros \& Mayer, 2010), the Greek banks did not buy U.S. subprime-backed bonds, or pay themselves extortionate bonuses. Instead, they had lent $€ 30$ billion to the government, where it was "stolen or squandered. In Greece the banks didn't sink the country. The country sank the banks" (Lewis, 2011, p.46).

Greece had experienced rapidly increasing current-account deficits, meaning the value of goods and services a nation imports exceeds the amount it exports (Holinski, Kool \& Muysken 2012; de-Cordoba, Pujolas \& Torres 2013). Furthermore, government spending on public workers and pensions among other things were at unsustainable levels prior to the crisis. However, at the time, it was common consensus that a current account deficit among Eurozone countries would not be a major concern (Blanchard \& Giavazzi, 2002). 
In 2009 , the government deficit had reached $15.5 \%$ of GDP and in order to avoid defaulting on their debt, Greece requested a $€ 110$ billion euro loan from the Troika (IMF, 2010). In order to ensure these loans were well invested, the Troika forced Greece to take on fiscal consolidating measures known as austerity. Austerity was deemed necessary in order to reduce the budget deficit to below $3 \%$ of GDP, a target set by the EU. In order to achieve this, the government would need to reform tax collection, reduce public sector incomes and scale down social security programs (Pappas, 2014, p.74). The program got off to an 'impressive start' with major reforms ahead of schedule (IMF, 2010). Regardless of this parliamentary opposition was widespread and protests were becoming more regular and more violent. The country was, and remains, in an unstable financial state. The debt-to-GDP ratio reached $180.1 \%$ in 2014 , whilst unemployment peaked at $27.9 \%$ in July 2013 (Papaconstantinou, 2016). Greece is yet to show proper signs of recovery.

\section{Literature Review}

What differentiates the Greek case from many of the other bailout nations is the fact that for decades they had been run by populist politics. After the financial crisis, a more extreme version of populism came to the forefront. By examining other theories on the rise of populism in Europe one can gain a greater understanding of this phenomenon.

As stated in the introduction, populism can take on a number of forms with different characteristics and is thus difficult to define. Populism can be viewed as an ideology that separates society into two groups of people, the people and the corrupt elites (Mudde, 2004; Kriesi \& Pappas, 2015). By opposing the existing 'undemocratic liberalist' political society, what has in the past been primarily made up of pluralists and elites, the European electorate has shifted course. Instead, they have built a political agenda on morality and simplicity. Large parts of European electorates do not feel the political elites are addressing important issues, whilst many feel they are powerless due to the existence of powerful entities such as the United States, or the European Union (Mudde, 2015). Moreover, recent forms of populism have been driven by leaders far more adequate at debating compared to their former populist counterparts. These leaders can often match the conventional party's leaders in debate whilst, simultaneously, being more attractive to the electorate through, for example, social media (Mudde, 2015). A major difference between Mudde, Canovan and Taggart is that Mudde focuses primarily on the existence of illiberal politics rather than defining key features within populism. For this reason, it is not reasonable to study Mudde along with Canovan and Taggart.

Another important development in recent times has been the mass globalization and the existence of 'losers of globalization' (Pauwels, 2014). These can be characterized by low levels of political trust, dissatisfaction with democracy, lower levels of education, ideological extremism, weakness of social ties and Euroscepticism (Pauwels, 2014, p. 58-66). Losers of globalization create three new political cleavages with clear winners and losers. These conflicts are; economic competition, cultural diversity and political integration. Due to fear of competition from immigrants and other 
nations, low-educated workers tend to turn to populist politics (Kreisi et al, 2012). However, this theory is not uncontested as a number of globalization 'winners' also turn towards populist politics, especially on the right (Mudde, 2007). This was the case in Greece, as "those protesting most vehemently were usually not the weakest... the most vocal were the high earning civil servants whose salaries we had cut" (Papaconstantinou, 2016, p.208).

Due to its lack of concise characteristics populism can exist across the political agenda from the far left to the far right (Canovan, 1981; Taggart, 2004; Mudde, 2004; 2015). Although differences in characteristics tend to exist between the left and right, the anti-elitist message tends to hold true across the political spectrum. Right-winged populism tends to have a common enemy, consisting of internal enemies such as homosexuals, external such as immigrants as well as international organizations such as the European Union (Mudde, 2004). This sentiment can be seen as consistent with the politics presented by Front National in France, the United Kingdom Independence Party in the UK and the Partij voor de Vrijheid in the Netherlands. However, Jan-Werner Muller (2016) argues that left-winged populism, although it can exist, should be defined differently. He shows this by drawing comparisons between Donald Trump and Bernie Sanders, pointing out why Trump is a populist whilst Sanders is not. Although they both ran an anti-establishment campaign calling on a united people, typical of populist politics, Sanders because of his more socially aware political agenda should not be seen as a populist. This belief can be seen as slightly naïve as it appears Muller is blurred by his own political views. The Greek case, as will be shown, demonstrates how populism on the left can be as militant and antiestablishment as far right populism (Pappas, 2014). Pappas is the main source used for this research, however, the main focus of his work is on the metapolitefsi period (Pappas, 2014, p.2). By contrast, the research for this chapter focuses primarily on the post-metapolitefsi era. Furthermore, he does not compare theories of populism with the evidence he provides.

\section{Theoretical framework}

Margaret Canovan (1999) explores how populism arises in representative democracies. She defines populism as an "appeal to the people against both the established structure of power and the dominant ideas and values of the society" (p.4). The structure within which populism arises dictates its political style and mood. If, for example, populism arises in a nation with a commitment to high taxation and a generous welfare society, populism can embrace an economic liberalist agenda, whilst in a free market hegemony populists can demand further protectionism. According to Canovan populism has "the revivalist flavor of a movement, powered by the enthusiasm that draws normally unpolitical people into the political arena" (p.6).

Canovan bases her work on Michael Oakeshott who coined the terms 'politics of faith' and the 'politics of skepticism'. Politics of faith is the idea of achieving salvation through the government. It is an enthusiastic movement in which creativity surpasses structure. On the other hand, politics of skepticism is suspicious of both power and enthusiasm as it has a lower expectation of what government can achieve. Instead, government exists to keep order and reduce occasions for conflict via institutions and the legal 
system. Canovan used these ideas and developed them into the redemptive side of democracy and the pragmatic side, respectively. She argues "that democracy presents two faces, one redemptive, the other pragmatic; that although these are opposed, they are also interdependent; and that between them lies a gap in which populism is liable to appear" (p.9).

Populism is likely to appear between the two sides in three ways. First, the pragmatic side exists to ensure we can coexist without violence in the midst of conflict through rules and practices. On the other hand, democracy is a redemptive vision, promising salvation through politics. The pragmatic side is necessary in order to ensure peace and order, but pragmatism without the redemptive impulse is a recipe for corruption (p.11). In this scenario, the lack of the redemptive side leads to populism as people grow tired of a political elite that is too focused on its own self-interest.

The second gap exists because in the redemptive vision the people are the only source of legitimate authority. This is in conflict with the pragmatic view of democracy. Pragmatically, democracy is simply a form of government. Although the redemptive side is wrong in assuming the people, who are characterized by a number of diverse interests and opinions, can come together into one coherent collective will, it is correct in assuming that a collective political will is more efficient than a purely pragmatic democracy (p.12). If a state lacks this collective will, populism will arise bringing the people together.

Lastly, the third tension between redemptive and pragmatic democracy concerns democratic institutions. Pragmatically, institutions are necessary as they ensure effective and long-lasting rule but they create a division between those in power and the people. As Canovan argues "it is important for democratic legitimation that the polity be seen as being in some sense an expression of the people: that (whatever we may think of the incumbent government) the state is our state, not something altogether alien to us" (p.13). If the gap between institution and populace becomes too large, the pragmatic ability to resolve conflict without violence is damaged.

Paul Taggart (2004) explores the key tenants of the 'ideal' functioning of populism. Firstly, populism is hostile to representative politics. Although populism can exist without the institutions and the ideology of representative politics exists, it is only under "the conditions created by representative politics that it can become a political force or that we can talk about it as a set of ideas" (p.273). With the institutions of modern representative politics populism can transform from a mere cultural element to a political movement or at the very least a political ideology. Populists tend to be put-off by the 'horizontal' lines between elites who gain from society, and call for a more 'vertical' access of the masses to the elites (p.273).

Second, populists tend to identify themselves with a 'heartland'. A heartland means a "past-derived vision projected onto the present as that which has been lost" (p.274). When populists refer to the 'people' they are infact referring to their vision of the heartland of the past that has been lost.

Third, populism lacks core values. From the heartland a number of key core values are derived, and since the heartland is not the same for everyone, the variety of versions of heartlands explain the variety of ideologies populism is attached too. Hence, this explains why populism can exist both on the left and the right side of the political spectrum. For this reason "populists mobilize when their heartland is threatened, not when a 
heartland is threatened" (p.275).

Fourth, populism is a reaction to a sense of extreme crisis. Populism is not the "politics of the stable, ordered polity but comes as an accompaniment to change crisis and challenge" (p.275). This crisis can be a financial one, but also a moral one and leads to a shift in the political arena as conventional representative politics is seen as the scapegoat as to why present society is the way it is.

Lastly, populism has a self-limiting quality. As populism presents itself in the face of a crisis, populism is not a constant political entity but a constantly changing one. For this reason, it is difficult to sustain populist movements in the long-term. The mass appeal of populism is its opposition to conventional politics, hence when populist become institutionalized it is difficult to maintain that status quo (p.276).

\section{Case Selection}

The case selection for this research is post-crisis Greece. The situation in Greece prior to the crisis has been explored in-depth by a number of scholars showing how the institutional weaknesses of both Greece and the EU created a scenario in which the state could fall (Mishkin, 2011; Papaconstantinou, 2016). This is important as the financial crisis did not just affect the state of the economy in nations, but "in the countries hardest hit, the economic crisis developed into a deep political crisis" (Kriesi \& Pappas, 2015, p.2). Greece has, as a consequence of the financial crisis, shifted from a purely economic crisis to a political and societal crisis. The social unrest in Greece since 2009 goes beyond what any of the other bailout nations experienced. As Greece was the Eurozone country worst hit by the crisis, has been most resistant to change, and had the most regularly occurring and violent political protests it makes it the stand out case in comparison to the other bailout countries. Furthermore, the political arena in Greece has been far more tumultuous in comparison to many other nations as in the face of institutional and cultural crisis, the people have turned to populist parties such as SYRIZA and GD.

A number of studies on contemporary Greece and populism have been conducted. However, scholars, including Pappas, have yet to apply the Greek case to the key existing populist theories. By applying empirical evidence to well-regarded theories, the Greek case will not only show to what extent these theories are transferable and applicable, but potentially how exemplary the Greek case really is. Greece provides us with the 'crucial case' meaning the case providing the most "distinctive type of empirical evidence for inductive theory building" (Eckstein, 1975, p.118). Inductive theory building is the act of studying observations and developing theories from these observations. Although this chapter is based on a theoretical framework provided by both Taggart and Canovan, it is only after these observations that one can generate theories on whether Greece is a stand out case, or can in fact be explained by these theories. 


\section{Analysis}

A contextualization of post-metapolitefsi populism in Greece and how it arose and functions is necessary to then analyze the two theories.

\subsection{1-2009}

From 1981-2009 Greece developed as a populist democracy, meaning a democratic subtype in which the party in government and the major opposition party are both populist (Pappas, 2013; 2014). Due to the constant swapping of governance and the populist nature of governance, political patronage was developed and eventually became systemic. Patronage is the link between politicians and voters "based on direct material inducements targeted to individuals and small groups of citizens" (Kitscheld \& Wilkinson, 2007, p.2). The electorate gained significant tangible and nontangible advantages when their party were in power such as jobs, higher pensions and even immunity from the law. Since society had been divided into two irreconcilable parts represented by populist parties regularly alternating in power, all citizens could expect to gain from patronage once their own party was in office. Table 1 shows how national elections was divided between ND and PASOK from 1981-2009.

Table 1: PASOK and ND electoral cycles, 1981-2009

\begin{tabular}{lcccccccccc}
\hline & 1981 & 1985 & 1990 & 1993 & 1996 & 2000 & 2004 & 2007 & 2009 & $1981-2009$ \\
\hline PASOK & 48.1 & 45.8 & 38.6 & 46.9 & 41.5 & 43.8 & 40.6 & 38.1 & 43.9 & 41.4 \\
ND & 35.9 & 40.9 & 46.9 & 39.3 & 38.1 & 42.7 & 45.4 & 41.8 & 33.5 & 40.6 \\
Total & 84.0 & 86.7 & 85.5 & 86.2 & 79.6 & 86.5 & 86.0 & 79.9 & 77.4 & 82.0 \\
\hline
\end{tabular}

Source: Pappas, 2014, p. 54

The conundrum in Greek populist democracy is that it displays the format of a two party system, but produced the mechanics of polarized pluralists (Sartori, 1971, p.188). Typically, two party systems display signs of moderation as each side converges towards the center of the party-competition space. In Greece, this was not the case as political actors used "polarization to divide society along a single cleavage, thus creating two political camps identified in opposition to each other" (Pappas, 2014, p.53).

As can be seen, already during the metapolitefsi era, the redemptive side of democracy had been far more apparent than the pragmatic side. The weakness of institutions and unwillingness to implement necessary change existed because Greece was run by populist politics. Populist politics by definition is more redemptive than pragmatic as it is a call on salvation for 'the people' through the people. However, by completely neglecting the fiscal side of the economy, the state depended on loans in order to keep the electorate happy, and to keep their populist persona alive. Public sector debt jumped from $39.4 \%$ of GDP to $109.2 \%$ of GDP in $1980-1990$ (OECD, 1991, 
p.13). Along with the average wage for workers, the number of civil servants increased drastically as well. By 2009, the number of civil servants exceeded one million, approximately $22 \%$ of the active workforce (INE, 2009, p.179). The reason for this was an increase in public expenditure and decreasing productivity. Furthermore, when unpopular stabilization programs were attempted, they were quickly abandoned as governments, due to pressure from workers unions, were forced to satisfy their electoral clientele.

Understanding the situation in Greece prior to the financial crisis is important as Canovan's theory is based on the assumption that the preexisting government is a functioning one. The debt crisis along with the influence of the Troika forced PASOK into a more pragmatic, central position, emphasizing the importance of fiscal discipline. However, when a society has existed under the pre-tense of false governance for so long it is difficult to welcome a system of governance that no longer offers the same sort of advantages, especially one that has been forced to transform due to an outside force.

\subsection{Strikes and political opposition in 2008-2012}

Political strikes were far more common in Greece than in any other crisisridden European country and had become engrained into society as a method for the people to get what they wanted (Pappas, 2014, p.94). During the years of populist democracy that preceded the economic crisis, "the protesting society had successfully prevented governments, whether of the center-left or the center-right from rationalizing the state and introducing market reforms... every single effort during that period to reform the state and restructure the economy was met with hostility and often became the cause of ferocious political squabbles" (Pappas, 2014, p. 92). By the end of 2010 about $30 \%$ of the entire population had engaged in some type of protest during the year (Rudig \& Karyotis, 2013, p.23). Protests during the crisis era were not limited to the 'globalization losers' but involved people from all sections of society. Protests included "disappointed right-wingers and leftwingers, conservatives and over-eager patriots. Both rich and poor. There has never been a more diverse group of protests gathered in the same place for the same purpose in recent Greek history" (CNN iReport, 2011).

The first of the major demonstrations was the youth revolt in 2008 where protests against a teenage boy being shot by a police officer took place. This created chaos akin to a low intensity civil war (Kalyvas, 2010, p.353). However, the roots of the protests were deeper than the shooting of a young boy. They were "directed at a political system and state behavior which Greek youths believed had let them down" (Economides \& Monastiriotis, 2009, p.vii). What had brought these people together was the common belief that their state had led them down and that "the authoritarian Greek state and the corrupt order of the metapolitefsi became enemy number one" (Papadimitriou, 2009, p.49).

Opposition to the austerity measures went beyond the streets. One possible explanation as to why strikes were so widespread was the political opposition in Greece. The opposition parties in 2009, primarily ND, "refused to accept their responsibility for the situation the country found itself in, or to lend support to the only possible way out.... For the following two years, Greece became the only one of the bailout countries without cross-party support for the adjustment effort - and the country paid dearly for its 
populism" (Papaconstantinou, 2016, p.138). By the time ND had gotten on board with the austerity reforms, it was too late, as the populist sentiment had already spread across the nation. After 2012, the amount of strikes had subdued, however, this was mainly because SYRIZA had shifted tactic.

Instead of calling on the people to take to the streets to oppose austerity, they began opposing the programs in parliament (Papaconstantinou, 2016, p.256).

\subsection{Polarized pluralism}

Giovanni Sartori (1976) created the framework for a political arena characterized by polarized pluralism. The first feature is the existence of antisystem parties. These are similar to what Taggart called populisms hostility to representative democracy. The second feature is the center placement of a group of parties. Lastly, left and right opposition parties remain incompatible and cannot join forces (Sartori, 1976, p.131-173). A major difference between typical polarized pluralism as presented and Greece is that Greece lacks the last feature. Instead, voters can move freely between neighboring parties and between groups of parties. Table 2 shows a diagram which helps provide an analysis of the political arena in Greece since 2012.

Table 2: Greek party divisions, post-2012
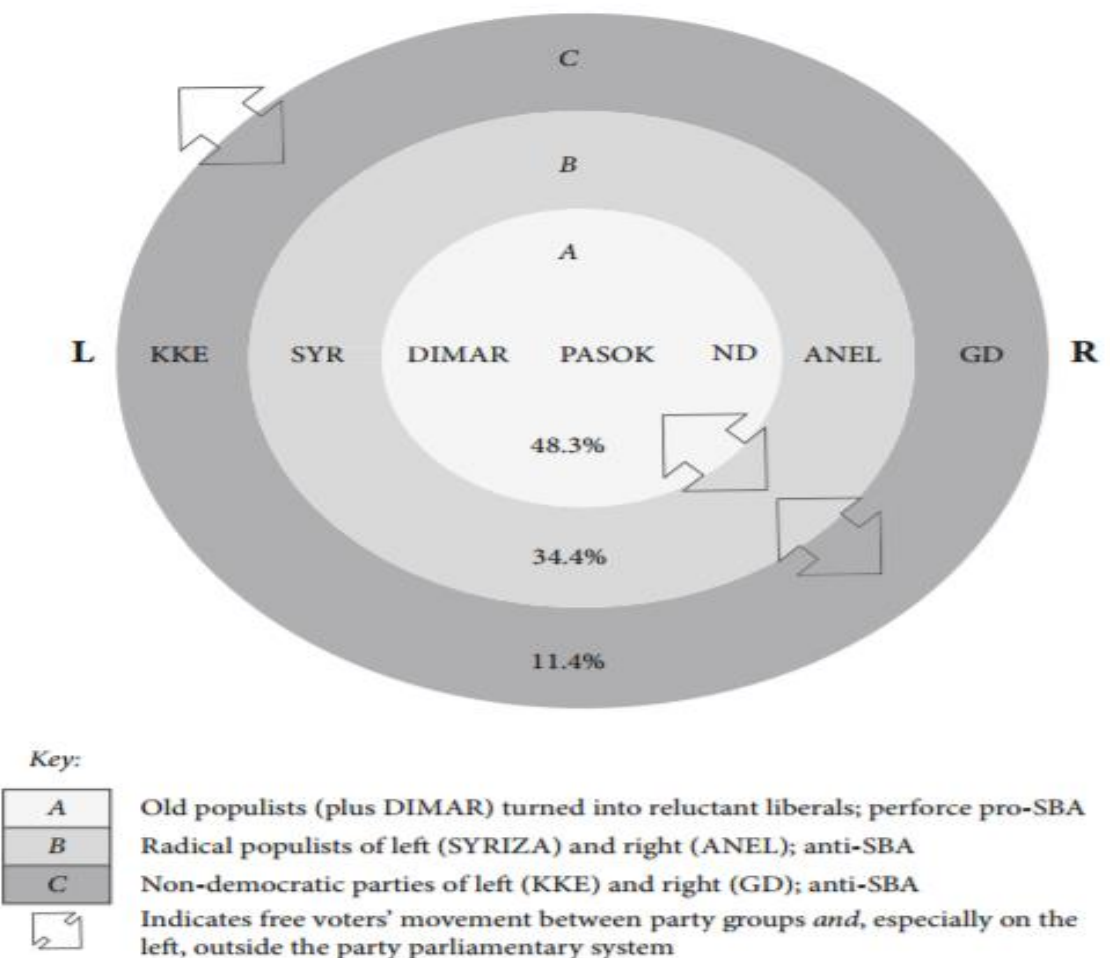

Old populists (plus DIMAR) turned into reluctant liberals; perforce pro-SBA Radical populists of left (SYRIZA) and right (ANEL); anti-SBA Non-democratic parties of left (KKE) and right (GD); anti-SBA Indicates free voters' movement between party groups and, especially on the left, outside the party parliamentary system

Source: Pappas, 2014, p.103 
As the diagram shows, section A contains the old populists who have turned into reluctant liberals. These parties were for the Stand-By Arrangement (SBA) which allowed for the bailout with the Troika, keep Greece in the Eurozone as well as saving it from default. Section B contains the radical populists. These parties opposed the current functioning of the 'neoliberalist' agenda of the EU. However, they hoped to overthrow PASOK and ND through democratic elections. Section C contains the extreme nondemocratic populist parties. After the 2012 elections, as the diagram shows, voter movement from the left to the right political spectrum is not just possible but common. Furthermore, party allegiances across the political spectrum exists. Pappas argues that although SYRIZA and ANEL are on opposite sides of the spectrum "these two parties often reach out to each other, seeking to set up a common social and political front in support of similar goals and against their common enemies" (Pappas, 2014, p.113). Even KKE and GD although being ideologically incompatible share a hostility to representative democracy and the rule of law.

\subsection{Nature of post-metapolitefsi populism}

Although Canovan does not present the importance of protests directly, they were, in this case, a symbol of redemptive revolt against the lack of pragmatic leadership in past years. This the nature of post-metapolitefsi populism in Greece. It was a criticism against the elites and state by a collection of globalizations 'losers' and 'winners'. Without realizing their own role in the predicament they were faced with, as the people had blocked any attempt at reform, people called for a better run state. However, as the state finally began adopting a more pragmatic form of governance through the help of the Troika, which helped install functioning institutions and reformed the tax system, people turned to more extreme forms of populism in a revolt against this. As Pappas argues "the Greek people had become angry. But not because they could not earn enough during the crisis; it was because they had lost what they were given foolishly, and by and large unjustifiably, before the crisis hit" (Pappas, 2014, p.99). What the Greek people failed to understand was that only through institutional reform would the austerityreforms work.

The paradox of the post-metapolitefsi populism is that people turned to populism to solve the problems that populism had created. This created, in the 2012 elections, a cleavage, "effectively pitting Greeks who saw painful reforms as necessary to achieve future gains against Greeks who oppose reform for fear of losing past benefits" (Pappas, 2014, p.102).

\section{Discussion}

The two theories will be analyzed separately and then evaluated on their relevance to the Greek case as described above. Each key tenet of the respective theories will be analyzed. 


\subsection{Rise of populism}

Comparing the key tenets of Canovan's claim one can see distinct features of similarity and differences in the case of Greece. Canovan makes one key assumption that limits her theory - that the starting point is a functioning democracy. As the previous section has shown, Greece was by no means a well-functioning democracy within which the pragmatic and redemptive sides both existed. She argues that "when too great a gap opens up between haloed democracy and the grubby business of politics, populists tend to move on to the vacant territory, promising in place of the dirty world of party maneuvering the shining ideal of democracy renewed" (Canovan, 1999, p.11). Populism in Greece had been the main rhetoric of governance from the start of their modern representative democracy. What was necessary for Greece was more pragmatism, not less. When this finally arrived, people feared losing what they had unrightfully gained during the decades of populist rule. What happened in Greece from 2008-2012 was the actual closing of the gap between the 'haloed democracy and the grubby business of politics', as governments could no longer involve themselves in behind the curtains affairs, especially not with the watchful eye of the Troika looking over their every move.

Canovan argues that without a collective ideology populism will eventually take the role of uniting the people. However, in order to enforce a collective ideology, institutions are needed. In the case of Greece, as previously argued, political opposition was widespread. If no collective ideology can exist in parliament then how can a government expect it to thrive amongst the people? Canovan states "one of the reasons for the comparative power of some states and the weakness of others is the presence or absence of this kind of collective political will" (Canovan, 1999, p.13). The second cleavage is therefore very relevant to the Greek case.

The third aspect of tension between the redemptive and pragmatic sides of democracy concerns democratic institutions and "the alienation to which they inevitably give rise" (Canovan, 1999, p.13). Entwined within the redemptive side of democracy is an anti-institutional sentiment, and a craving for unmediated expression of the peoples will. Although institutions are needed in maintaining power, making it effective and long lasting, they alienate the people from governance. This may be applicable to the rise of populism in a functioning democracy. However, the Greek starting point was so poor that such an argument holds less value. In the face of complete disregard for institutions, institutions need to be implemented. Prior to the crisis Greece had no Congressional Budget Office, instead "the party in power simply gins up whatever numbers it likes, for its own purposes" (Lewis, 2011, p.48). It is important for democratic legitimation that the polity be seen as being in some sense an expression of the people: that the state is our state, not something altogether alien to us. Where this is not the case, "the pragmatic ability of democracy to resolve political disputes without violence is damaged" (Canovan, 1999, p.13). The mass strikes and protests show that they had 'lost' this ability. However, what is clear is that the Greek government had never had this ability, although the number of strikes increased, Greek society had relied on strikes for decades. 


\section{2 'Ideal' functioning of populism}

Paul Taggart focused on the role of populism in representative politics. The approach he takes is focused on finding the "common features to populism and to further suggest that identifying these common features enables us to build up a universally applicable approach to populism" (Taggart, 2004, p.273). The main point of criticism against Taggart in the case of Greece is that he makes the same assumption as Canovan. Namely, both pre-suppose a fairly well functioning form of democracy. However, as has already been shown, this was not the case. In order to decide whether Taggart's theory on populism fits with the Greek case, each of the five tenets of his theory will be examined.

The first feature is that populism is hostile to representative politics as it searches for "vertical access of the masses to the elites" (Taggart, 2004, p.273). Populism in Greece had already for a long time prior to the financial crisis developed from a cultural '/eitmotif' to a fully-fledged political movement. For this reason, Greek politics had for decades been run by a direct link between the masses and the political elites. This meant that Greece did not suffer from a representative democratic deficit as is the case in many other populist nations. Furthermore, as can be seen by table two, seven major parties exist in Greece. However, they can only take the polity positions of three forms: liberal democratic, illiberal democratic and non-democratic. Pappas argues "rather than viewing the parties along a spatial configuration (which would yield two lefts, two rights and a center) it is much more sensible to examine them on the basis of whether they stand for or against representative democracy and, among these which stand for it, whether they favor a liberal or a populist type of democracy" (Pappas, 2014, p.105). In the face of new populism, former foes in PASOK, ND and the Democratic Left (DIMAR) created a coalition government. This explains why the left, SYRIZA, and the right, ANEL, are politically closer than the distance separating each of these parties from the center parties of PASOK and ND. Pappas argues that although SYRIZA, GD and the Communist Party of Greece (KKE) all oppose the liberal democracy, ANEL is yet to make their opinion on this position clear (Pappas, 2004, p.112). Therefore, Taggart's first theme does not fully apply as, although a number of populist parties in Greece oppose the current state of representative politics, they do not all share this common feature. Furthermore, until reform attempts by the Troika were imposed, Greece did not suffer from a domestic representative democratic deficit.

The second feature is that populism identifies with a heartland. This was definitely the case in Greece. One of the key tenets of the populist rhetoric was the anti-austerity, anti-foreign involvement rhetoric. As Panos Kammenos, leader of the right-wing Populist Party, Independent Greeks (ANEL) said in an electoral speech: "There are people who believed for years both in ND as well as PASOK. I tell them clearly then that the present ND is not that of Constantine Karamanlis, which brought Greece into Europe. And the present PASOK is not that of Andreas Papandreou proclaiming that 'Greece belongs to the Greeks'; this is the PASOK that relinquishes national sovereignty" (Pappas, 2014, p.110). This sentiment was not only visible within the populist parties but amongst the 'new' liberal center party in PASOK and ND. Although PASOK had voted for the bailout packages the MPs were "intent on challenging every single bill that would come before them. As one of our [PASOK] MPs put it 'we have been colonized'" (Papaconstantinou, 
2016, p.154).

At the flanks of the new party system, GD, claims to "speak the secret voice of the Greek blood that survives unaltered through thousands of years of history until today and promises to overthrow the corrupt system of governance and establishes a classless, organic people's state inspired by the nationalist ideology" (Pappas, 2014, p.111). However, the Greek heartland is divided along a cleavage (Diamandouros, 1994). One side originating from "Western European liberalism, and represents the forces of pluralism, open market and secularism; the second undercurrent, originating from Greece's Ottoman past and the traditions of the Eastern Orthodox Church, represents nationalism, reliance on the state, xenophobia and suspicion of the market mechanism" (Pappas, 2014, p.4). This cleavage helps further explain why the debate between the 'reluctant liberals' in PASOK and ND and the populist parties clash. PASOK and ND represent the modern side in search for an explanation and solution to the moral and financial crisis, whilst the populist parties represent the traditional side of the debate. Taggart's second theme therefore applies to the Greek case.

The third feature is that populism lacks core values. According to Taggart "the variety of versions of the heartland explains why populism is attached to some very different ideological positions from the left to the right" (Taggart, 2004, p.274). In Greece, the populist parties, although they do not share the same political ideology, have similar core values that exists across the political arena due to a well-defined common enemy in the Troika and their Greek 'puppets'. Therefore, parties manage to align themselves with parties on opposite spectrums despite their ideological differences. However, Taggart's reasoning is that the core values of populist parties across different heartlands differ. The scope of this research is limited in that it focuses on a single case of Greece and so analyzing this theme to its fullest is difficult. Nonetheless, SYRIZA and the left-winged Spanish anti-austerity party, Podemos, share core values across different heartlands. SYRIZA drew inspiration from Podemos anti-austerity marches. Furthermore, similar to SYRIZA, Podemos "is the expression of the diversion and blockade of the rising class struggle that followed the capitalist crisis" (Lotito \& Martinez, 2016). Not only did they arise from the same crisis, they are championing similar views such as pro debt-restructuring, Euroscepticism, and antiGerman, anti-American sentiments (Roman, 2015). Given the similarities between Podemos and SYRIZA, it can be argued that core values can exist amongst populist parties even if they do not share the same heartland thus Taggart's third feature is not applicable.

The fourth feature is that populism is a reaction to a sense of extreme crisis. According to Taggart "populism is not the politics of the stable, ordered polity but comes as an accompaniment to change, crisis and challenge" (Taggart, 2004, p.275). This crisis need not be financial, but can be a moral or societal one as well. In such a circumstance, populism promises that the existing polity is incapable of dealing with the crisis. In the case of Greece, the sovereign debt crisis was the sparkplug for the anti-austerity populism, but a moral crisis had existed in Greece for decades with no sign of change. This can be explained by the paradox of Greek populists who had no objection to the unjust privileges they had gained from their government.

Corruption and tax evasion was widespread to such an extent that it was engraved in society itself. Michael Lewis (2011) argues "the Greek state 
was not just corrupt but also corrupting... the epidemic of lying and cheating and stealing makes any sort of civic life impossible; the collapse of civic life only encourages more lying, cheating and stealing" (p.54-55). However, this changed with the Vatopaidi scandal in 2008 in which a number of monks from the Vatopaidi monastery had successfully traded low-value land for high-value property in a deal which ran directly through the office of ND prime-minister Kostas Karamanlis (Lewis, 2011, p.63-64). According to Pappas "the combination of political and economic crises that afflicted Greece from December 2008 caused the detachment of voters from traditional parties, the emergence of contentious challengers, the shattering of former party allegiances, the demolition of the old left-right cleavage bases, and, eventually, the complete destruction of two-party politics" (Pappas, 2014, p.108). The moral and financial crisis in Greece was key in creating the groundworks for the post-metapolitefsi populist movement. However, the societal issues existed for decades prior to the 2012 elections, and continue to exist today. Without radical state reform, which is not possible under populist governance, the moral deficit in the Greek state will continue to survive.

The last feature is the self-limiting quality of populism. As populist parties become institutionalized they tend lose a major part of their populist appeal. SYRIZA became the governing party based on a promise to reverse the austerity measures, bringing a tougher negotiation tactic to the European Institutions. SYRIZA was convinced that if they rejected a new bailout, European leaders would buckle under the pressure of a potential financial and political unrest. In light of this belief, Alexis Tsipras, the charismatic leader of SYRIZA and since January 2015, new prime-minister, called for a referendum in July, 2015. This would decide whether Greece should adopt yet another bailout package to which $61 \%$ of Greeks responded 'no' (Papaconstantinou, 2016, p.282). However, the EU did not buckle. Instead, they forced the new Greek government to adopt reforms, to meet all debt obligations fully and even turned off "the liquidity tap at the ECB, and refused to give a penny of additional financial support until Greece complied" (Lapavitsas, 2016).

Eventually, Tsipras surrendered to the Troika, accepting yet another austerity package, and requesting another loan of $€ 53.5$ billion for 2015-2018 and committed to fiscal measures in excess of $€ 13$ billion (Lapavitsas, 2016). As Papaconstantinou (2016) stated, "so much for tearing up the memorandum in broad daylight and for using the no vote to get a better deal" (p.284). SYRIZA was the first example of "a government of the left that has not simply failed to deliver on its promises but also adopted the program of the opposition, wholesale" (Lapavitsas, 2016). Tsipras claimed he was surprised by the reality of the difficulties he had had to face and so called for a national election in September of 2015. SYRIZA won the election with 35\% (Papaconstantinou, 2016 , p.294). However, a recent opinion poll showed that ND had recaptured its lost votes prior to the crisis, whilst eight in ten Greeks gave a negative view of the government's performance in the past two years (Chrysopoulos, 2017). The crisis of confidence has persisted in Greek society, as yet another party failed to achieve what the Greek people have wished for. Taggart's last theme applies to the Greek case as has been shown by the self-limiting quality of SYRIZA and ANEL once in power. 


\section{Conclusion}

This chapter aimed to shed light on the rise of post-metapolitefsi populism in Greece, and whether two of the leading theories on populism apply to the Greek case. Using Pappas (2014) as a benchmark on the arrival and functioning of populism in Greece this chapter has developed upon his work by comparing it to theories on the rise of populism by Canovan and the 'ideal' type of populism by Taggart.

Both theories are limited in that they make the same assumption. They assume populism arose from a functioning democratic system. However, as has been shown, due to Greece's populist past, Greece has exhibited a permanent failure of elementary democratic institutions. For this reason, Canovan's theory is limited in that the gap between the redemptive and pragmatic has always existed. Greek populists rightfully demonstrated against the government for the situation they were in. However, when the pragmatic side of governance finally began to close the gap by enforcing the pragmatic side of democracy, Greeks turned to populist governance in hopes that they could salvage some of what had been lost as a direct cause of the debt crisis and austerity measures. Although the government was no longer an extension of the people's wishes, the lack of proper governance prior to the crisis forced PASOK to take a number of unwelcome and difficult reforms. However, the political opposition and the fear of losing what had been unrightfully gained through political patronage meant PASOK could not see their reforms through. Taggart's theory is based on five main tenets. Two of these, the existence of a heartland and the self-limiting quality of populism are both very clear in the Greek case. However, not all populist parties have shown a resistance to representative democracy. Furthermore, SYRIZA and Podemos have shared a number of core values despite their different heartlands. Moreover, although post-metapolitefsi populism arose as a consequence of the financial crisis, a societal and political crisis had existed for a long time before this, and continues to exist to this day. In conclusion, both theories make the same crucial assumption which limits their transferability to the Greek case.

Namely, the idea that the starting point is a functioning form of democratic governance. When this is not the case, or in the face of extreme crisis, these theories no longer hold true.

Although this chapter has explored weaknesses in each of the theories, it too holds limitations. Primarily, by using a single-case study the work is not very transferable, thus it merely shows that these theories are not fully applicable to the Greek case, and not populism in general. Furthermore, this research does not present an alternative model to those analyzed, but merely shows weaknesses of the theories.

The Greek struggle stands out for many reasons. In order for similar situations to be avoided in the future, it should be thoroughly studied by scholars and governments alike. Hopefully, Greece may one day regain what it has lost from the crisis as well as incorporate the many lessons they have learned to better the living standards for future generations. 